\title{
Deficit Irrigation Effects on Cabbage (Brassicaceae Oleracea var. capitata L. Grandslam F1) Yield in Unheated Greenhouse Condition
}

\section{Hakan Büyükcangaz*}

Biosystems Engineering Department, Faculty of Agriculture, Uludağ University, 16120 Bursa, Turkey

\section{A R T I C L E I N F O}

\section{Research Article}

Received 18 May 2018

Accepted 01 August 2018

Keywords:

Evapotranspiration

Cabbage

Water use efficiency (WUE)

Yield and quality parameters

Irrigation scheduling

*Corresponding Author:

E-mail: cangaz@uludag.edu.tr A B S T R A C T

The aim of this study was to determine the effect of deficit irrigation on yield for cabbage grown under unheated greenhouse condition. The research was carried out at the Agricultural Research Station of Yenişehir High School of Uludağ University in Bursa, Turkey, in 2008. In the study, water was applied to cabbage as 1.00, 0.75, 0.50, 0.25 and $0.00 \%$ (as control) of evaporation from a Class A Pan corresponding to 2 day irrigation frequency. Irrigation water applied ranged from 70 to $520 \mathrm{~mm}$ and water consumption ranged from 90 to $548 \mathrm{~mm}$. The effect of irrigation water level on the yield, head height, head diameter, head weight and dry matter were found to be significant. The highest yield was $72.8 \mathrm{t} \mathrm{ha}^{-1}$. Crop yield response factor for cabbage $\left(\mathrm{k}_{\mathrm{y}}\right)$ was found as 1.036. The highest values of water use efficiency (WUE) and irrigation water use efficiency (IWUE) for 2008 year of $\mathrm{K} 2_{\mathrm{cp}}$ treatment was calculated to be $0.143 \mathrm{~kg} \mathrm{~m}^{-3}$ and $0.137 \mathrm{~kg} \mathrm{~m}^{-3}$, respectively. $\mathrm{K} 22_{\mathrm{cp}}$ application $(75 \%)$ can be recommended as the most effective irrigation level for the cabbage to which drip irrigation is applied under scarce and unheated greenhouse conditions.

DOI: https://doi.org/10.24925/turjaf.v6i9.1251-1257.2025

\section{Introduction}

Greenhouse cultivation, also known as protected cultivation, is one of the farming systems widely used to provide and maintain a controlled environment suitable for optimum crop production leading to maximum profits. This includes creating an environment suitable for working efficiency as well as for better crop growth (Aldrich and Barto, 1989). Greenhouse cultivation is a steadily growing agricultural sector all over the world (Enoch and Enoch, 1999; Von Elsner et al., 2000). The type of structure primarily used in Turkey is the so-called Mediterranean greenhouse; low-cost, unheated plasticcovered structures and with soil- grown crops.

China, India, and Russia are the world's three biggest cabbage producers with 33400000,9000000 and 3500 000 tons, respectively (FAOSTAT, 2014). Russia is the largest cabbage consuming country. Turkey is one of the significant cabbage producer with 785791 tons in the world (FAOSTAT, 2016).

Cabbage is believed to have evolved from a wild form native to Europe, growing along the coast of the North Sea, the English Channel and northern Mediterranean. Cabbage is a popular vegetable throughout the world because of its adaptability to a wide range of climatic conditions and soil, ease of production and storage, and its food value. Cabbage is a favourite cuisine dish in our country, and it is eaten raw and also prepared by various methods as wrap, stew, salad and pickle (Vural et al., 2000).

Irrigation scheduling involves preventing the soil water deficit from falling below some threshold level for a particular crop and soil condition. This may involve estimating the earliest date to permit efficient irrigation or the latest date to avoid the detrimental effects of water stress on the crop (Ritchie and Johnson, 1990). Scheduling water application is very critical to make the most efficient use of drip irrigation system, as excessive irrigation reduces yield, while inadequate irrigation causes water stress and reduces production.

The optimum use of irrigation can be characterized as the supply of adequate amount of water to meet the crop needs in the root zone, and at the same time, avoiding the leaching of nutrients into deeper soil layers (Kruger et al., 1999). High frequency water management by drip irrigation minimizes soil as a storage reservoir for water, provides at least daily requirements of water to a portion of the root zone of each plant and maintains a high soil matric potential in the rhizosphere to reduce plant water stress. On the other hand, the intensity of the operation requires that the water supply is kept at the optimum to maximize returns to the farmer. 
Irrigation scheduling with drip irrigation relies on approaches based on evapotranspiration estimations (BarYosef and Sagiv, 1982; McNeeish et al., 1985; Clough et al., 1990; Hartz, 1993) and allowable soil-water depletion (Bogle et al., 1989). A widely adopted method for estimating crop consumptive water use (CWU) is the pan evaporation method, which relates evaporation from a Class A pan to CWU. These two quantities are related by what is called the pan coefficient K. Irrigation scheduling based on the pan coefficient $\mathrm{K}$ is one of the simplest methods where no sophisticated instrument is required. Precise values for $\mathrm{K}$ are often difficult to establish, given regional and site-specification, soil characteristics, crop physiology and cultural practices. Any recommended value of $\mathrm{K}$ for regional irrigation scheduling program must be high enough to prevent water stress arising from emergencies and specialized local situations, while remaining low enough for efficient water management (Yuan et al., 2003). Based on the US Weather Bureau Class A pan evaporation, many studies have been completed on the irrigation of cabbage (Kiziloglu et al., 2008), broccoli (Ayas et al., 2011), tomato (Ayas, 2015); green bean (Büyükcangaz et al., 2008); pepper (Demirtas and Ayas, 2009), cucumber (Ayas and Demirtas, 2009), lettuce (Yazgan et al., 2008) and potato (Ayas and Korukcu, 2010; Ayas, 2013). Several studies have been performed to investigate the influence of different irrigation levels on cabbage growth and yield.

The objectives of this study were to provide a guideline for cabbage growers and to determine drip irrigated cabbage response to different irrigation regimes.

\section{Materials and Methods}

Field trials were conducted under unheated greenhouse conditions in the region of Bursa-Yenisehir (40¹5'09 "N latitude, 29 38'43"E longitude and altitude of $225 \mathrm{~m}$ above mean sea level). For experimental purposes, high tunnel type plastic covered greenhouse with the size of $8 \mathrm{~m} \times 40 \mathrm{~m}$ was built. The climate characteristics of the experiment area was hot and dry in summer and cold and rainy in winter. Annual average precipitation and temperature values for 2008 in the regions where greenhouse experiments were carried out was $630.7 \mathrm{~mm}$ and $12.9^{\circ} \mathrm{C}$, respectively. The average minimum temperature for 2008 were gauged as $-6.6^{\circ} \mathrm{C}$ in January while the average maximum temperature were gauged as $32.9^{\circ} \mathrm{C}$ in August (Anonymous, 2010). The soil of the experiment field was classified as sandy loam and soil $\mathrm{pH}$ ranged between 7.99 and 8.04. Some of the physical and chemical characteristics were presented in Table 1.

Mankozeb and Endosulfan were sprayed to the experiment fields as a chemical drug against diseases and insect pests. $170 \mathrm{~kg} \mathrm{ha}^{-1} 21 \% \mathrm{~N}, 50 \mathrm{~kg} \mathrm{ha}^{-1} 46 \% \mathrm{P}_{2} \mathrm{O}_{5}$ as bottom fertilizer was applied two weeks prior to sowing process. An additional $170 \mathrm{~kg} \mathrm{ha}^{-1} 46 \% \mathrm{~K}_{2} \mathrm{O}$ fertilizer was applied when the crops reached to height of $15 \mathrm{~cm} .10 \mathrm{~L}$ $\mathrm{ha}^{-1}$ chlorophyllous-ethyl was sprayed against insects.

Transplantation date of the cabbage seedlings to the plots were August 01 in 2008 year. In the experiments, row and plant spacing were $0.60 \mathrm{~m}$ and $0.60 \mathrm{~m}$, respectively. Each plot has contained 44 plants. 14 plants of middle row were harvested to consider side effects. The head height $(\mathrm{cm})$, diameter $(\mathrm{cm})$ and weight $(\mathrm{g})$ of cabbages were measured by callipers and the average of measured values was calculated. Dry matter content was determined by the separation and drying (at $65^{\circ} \mathrm{C}$ in drying oven) of fruits (two samples for each plot). The amount of dry matter of heads was determined by using (AOAC, 2000).

The order of the trial was set as a randomized block design with 3-replication and single factor, and 5 irrigation applications were randomly distributed to each blocks. The irrigation applications were created using five different crop evaporation coefficients $\left(\mathrm{K} 1_{\mathrm{cp}}: 1.00, \mathrm{~K} 2_{\mathrm{cp}}\right.$ : $0.75, \quad \mathrm{~K} 3_{\mathrm{cp}}: 0.50, \mathrm{~K} 4_{\mathrm{cp}}: 0.25, \mathrm{~K} 5_{\mathrm{cp}}: 0.00$-for control purposes). The amount of irrigation water was determined using below stated equation (Doorenbos and Pruitt, 1977; Kanber, 1984):

$$
\mathrm{IW}=\mathrm{E}_{\mathrm{p}} \times \mathrm{K}_{\mathrm{cp}} \times \mathrm{P}
$$

Where, $E_{p}$ is cumulative evaporation $(\mathrm{mm})$ for 2-day irrigation frequency, $\mathrm{K}_{\mathrm{cp}}$ is pan evaporation coefficient, and $\mathrm{P}$ is the percentage of wetted area. Evaporations that occurred in the 2 day irrigation frequency was measured using Class A Evaporation Pan that was held in the middle of greenhouse applications and drip irrigation method was used. The amount of irrigation water was measured with flowmeter devices at the gate of each plot. The needed irrigation water was provided from a deep well (3 $\left.\mathrm{L} \mathrm{s}^{-1}\right)$ that was drilled in the field. Quality properties of the irrigation water were presented in Table 2.

Irrigation water quality was low sodium risk and classified in $\mathrm{C}_{2} \mathrm{~S}_{1}$ with medium level EC value. Crop evapotranspiration (Cumulative evapotranspiration - $\mathrm{ET}_{\mathrm{c}}$ ) was calculated for 2 day irrigation interval using the below stated water balance equation;

$$
\mathrm{ET}_{\mathrm{c}}=\left(\mathrm{SWC}_{\mathrm{t} 0}-\mathrm{SWC}_{\mathrm{t} 1}\right)+\mathrm{IW}-\mathrm{D},
$$

Where $\left(\mathrm{SWC}_{\mathrm{t} 0}-\mathrm{SWC}_{\mathrm{t} 1}\right)$ is the change in volumetric soil water content $(\mathrm{mm})$; IW $(\mathrm{mm})$ and $\mathrm{D}(\mathrm{mm})$ are, irrigation water depth $(\mathrm{mm})$ and drainage $(\mathrm{mm})$ for the related period, respectively. Prior to irrigation water applications, water content in $0.60 \mathrm{~mm}$ soil depth was determined with gravimetric method (Lorenz and Maynard, 1980). Water content of the soil was monitored till 0.90 depth with increments of $30 \mathrm{~cm}$ depth following irrigation applications for each irrigation application. In subplots, the percolations below $0.60 \mathrm{~m}$ soil depth were omitted. In our study, the relationships between yield and ET were determined by the Stewart model (Doorenbos and Kassam, 1979):

$$
\left(1-\mathrm{Y}_{\mathrm{a}} / \mathrm{Y}_{\mathrm{m}}\right)=\mathrm{k}_{\mathrm{y}}\left(1-\mathrm{ET}_{\mathrm{a}} / \mathrm{ET}_{\mathrm{m}}\right)
$$

Where, $\mathrm{Y}_{\mathrm{a}}$ and $\mathrm{ET}_{\mathrm{a}}$ are actual crop yield productivity $\left(\mathrm{t} . \mathrm{ha}^{-1}\right)$ and cumulative evaporation $(\mathrm{mm})$, respectively, under insufficient irrigation conditions; $\mathrm{Y}_{\mathrm{m}}$ and $\mathrm{ET}_{\mathrm{m}}$ are maximum crop yield productivity $\left(\mathrm{t}^{\mathrm{h}} \mathrm{h}^{-1}\right)$ and cumulative evaporation $(\mathrm{mm})$ under sufficient water conditions. Yield 
productivity response factor of the deficit irrigated cabbage was presented with $\mathrm{k}_{\mathrm{y}}$. Water use efficiency (WUE) value was calculated to evaluate the irrigation efficiency in the applications. The two terms that are used to encourage the effective use of irrigation water in crop production phases are water use efficiency (WUE) and irrigation water use efficiency (IWUE). Water use efficiency (WUE) is calculated as the efficiency ratio of YLD to $\mathrm{ET}_{\mathrm{a}}$ and depicted as WUE $=\mathrm{YLD} / \mathrm{ET}_{\mathrm{a}}\left(\mathrm{kg} \mathrm{m}^{-3}\right)$. Irrigation water use efficiency (IWUE) was estimated with the below stated equation (Howell et al., 1990):

$$
\operatorname{IWUE}\left(\mathrm{kg} \mathrm{m}^{-3}\right)=\frac{\text { YLD-YLD }_{\text {rainfed }}}{\text { IRGA }}
$$

Where, YLD is yield value of each treatment plot $(\mathrm{kg}$

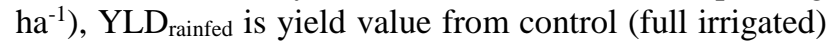
treatment plot $\left(\mathrm{kg} \mathrm{ha}^{-1}\right)$, IRGA is seasonal irrigation water amount $(\mathrm{mm})$. Cabbage seedlings completely grew and fruit had the yield productivity, head height, diameter and weight, colour and taste characteristics to its species, 90 days $(\mathrm{DOY}=90)$ after plantation, i.e. in harvest season. Yield productivity and quality parameters, i.e. head height, diameter and weight and dry matter ratio, were evaluated for each harvest season.

Variance analysis was conducted with yield productivity and productivity components by using MSTAT-C (version 2.1-Michigan State University 1991) and MINITAB (Texas University, Austin) software. The significance of irrigation applications was calculated at 0.05 and 0.01 probability levels with F-test (Steel and Torrie, 1980).

Table 1 Some of chemical and physical properties of experimental field soil

\begin{tabular}{l|cc}
\hline \multicolumn{1}{c|}{ Soil Depth $(\mathrm{cm})$} & $0-30$ & $30-60$ \\
\hline Unit weight of soil, $\mathrm{g} \mathrm{cm}^{-3}$ & 1.34 & 1.37 \\
Soil Texture & Sandy loam & Sandy loam \\
Field capacity, \% & 19.66 & 17.26 \\
Wilting point, \% & 11.94 & 9.98 \\
$\mathrm{pH}$ & 7.99 & 8.04 \\
Total salt, \% & 0.058 & 0.051 \\
$\mathrm{CaCO}_{3}, \%$ & 5.67 & 8.49 \\
Organic matter, \% & 2.94 & 1.39 \\
Available Phosphorus, kg da-1 & 1.53 & 1.24 \\
Available Potassium, kg da-1 & 38.35 & 19.52 \\
\hline
\end{tabular}

Table 2 Chemical composition of irrigation water used in the experiment

\begin{tabular}{l|c}
\hline \multicolumn{1}{c|}{ Parameter } & Value \\
\hline $\mathrm{EC}, \mathrm{dS} \mathrm{m}{ }^{-1}$ & 0.715 \\
$\mathrm{pH}$ & 7.12 \\
\hline Cations, me L' & \\
\hline $\mathrm{Ca}^{+}$ & 9.25 \\
$\mathrm{Na}^{+}$ & 2.3 \\
$\mathrm{Mg}^{+}$ & 5.7 \\
$\mathrm{~K}^{+}$ & 2.56 \\
\hline $\mathrm{SAR}$ & 0.85 \\
Class & $\mathrm{C}_{2} \mathrm{~S}_{1}$ \\
\hline
\end{tabular}

\section{Results}

Water Applied and Water Used

All treatments received $70 \mathrm{~mm}$ irrigation water to refill available soil water content of $0-60 \mathrm{~cm}$ soil depth up to field capacity level following planting date. Class A pan measurements of evaporation were just started after first irrigation water application. The maximum and minimum amounts of irrigation water applied were 520$70 \mathrm{~mm}$ for $\mathrm{K} 1_{\mathrm{cp}}$ treatment and $\mathrm{K} 5_{\mathrm{cp}}$ treatment, respectively. The amount of water applied to other treatments varied from 390 to $130 \mathrm{~mm}$. An increase in seasonal evapotranspiration $\left(\mathrm{ET}_{\mathrm{a}}\right)$ was observed with an increase at applied irrigation water. The actual evapotranspiration ranged between $548-90 \mathrm{~mm}$ for $\mathrm{K} 1_{\mathrm{cp}}$ and $\mathrm{K} 5_{\mathrm{cp}}$ treatments, respectively (Table 3 ).

Linear relationships between crop evapotranspiration $\left(\mathrm{ET}_{\mathrm{c}}\right)$ with yield productivity $\left(\mathrm{Y}_{\mathrm{a}}\right)$, and irrigation water (IW) with yield $\left(\mathrm{Y}_{\mathrm{a}}\right)$ were observed for 2008 year. The relationship equation is as follows; $\mathrm{Y}_{\mathrm{a}}=0.1542 \times \mathrm{ET}_{\mathrm{c}}-$ 9.0472 with $\mathrm{R}^{2}=0.99$ and $\mathrm{Y}_{\mathrm{a}}=0.1406 \times \mathrm{IW}$ with $\mathrm{R}^{2}=$ 0.99 (Figure 1).

The highest yield was obtained from $\mathrm{K} 1_{\mathrm{cp}}$ application with $72.8 \mathrm{t} \mathrm{ha}^{-1}$ for 2008 year. It was followed by $\mathrm{K} 2 \mathrm{cp}$, $\mathrm{K} 3_{\mathrm{cp}}$ and $\mathrm{K} 4_{\mathrm{cp}}$ applications with yield productivity values of 57.4-35.6 - $17.0 \mathrm{t} \mathrm{ha}^{-1}$, respectively. As expected, the minimum yield $\left(4.0 \mathrm{t} \mathrm{ha}^{-1}\right)$ was found from control $\mathrm{K} 5_{\mathrm{cp}}$ application in which irrigation was not applied. The yield productivity of non-irrigated $\mathrm{K} 5_{\mathrm{cp}}$ application was lower at a rate of $1720 \%$ in a comparison with $\mathrm{K} 1_{\mathrm{cp}}$ application. Moreover, lower yield productivity levels at a rate of 26.8 $\%, \quad 104.5 \%, 328.2 \%$ from $\mathrm{K} 2_{\mathrm{cp}}, \mathrm{K} 3_{\mathrm{cp}}$ and $\mathrm{K} 4_{\mathrm{cp}}$ applications were observed in a comparison with $\mathrm{K} 1_{\mathrm{cp}}$ application (see Table 4). Crop yields and quality are reduced due to water deficits applied particularly three or four weeks before harvest.

The related equations for 2008 year were as follows; head height $=0.0165 \mathrm{IW}+19.474$ with $\mathrm{R}^{2}=0.97$ (Fig. 2a.), head diameter $=0.0168 \mathrm{IW}+22.186$ with $\mathrm{R}^{2}=0.96$ (Fig. 2b), head weight $=0.0097 \mathrm{IW}-0.8507 .58$ with $\mathrm{R}^{2}=$ 0.95 (Fig. 2c.) and dry matter $=-0.0108 \mathrm{IW}+12.019$ with $\mathrm{R}^{2}=0.99$ (Fig. 2d.).

\section{Crop Yield Response Factor $\left(K_{y}\right)$}

Linear relationship between proportional decrease in water consumption and proportional decrease in yield productivity is depicted with crop yield productivity response factor $\left(\mathrm{k}_{\mathrm{y}}\right)$ that represents yield productivity response to be lowered in water consumption. In other words, it explains the decrease in yield productivity in relation with the decrease in water consumption per unit (Doorenbos and Kassam, 1979; Stewart et al., 1975). For irrigation application, seasonal yield productivity response factor $\left(\mathrm{k}_{\mathrm{y}}\right)$ was calculated as 1.036 for 2008 year (see Fig. 3). ky values increased with parallel to increase in water amount, except $\mathrm{K} 5_{\mathrm{cp}}$ application.

\section{Water Use Efficiencies}

Values of WUE and IWUE was lowered when the amount of irrigation water was reduced. The highest WUE and IWUE values for 2008 year were calculated from $\mathrm{K} 2_{\mathrm{cp}}$ application as $0.143 \mathrm{~kg} \mathrm{~m}^{-3}$ and $0.137 \mathrm{~kg} \mathrm{~m}^{-3}$, respectively. WUE and IWUE values of $\mathrm{K} 22_{\mathrm{cp}}$ application were found higher than other applications as $\mathrm{K} 1_{\mathrm{cp}}, \mathrm{K} 3_{\mathrm{cp}}$, $\mathrm{K} 4_{\mathrm{cp}}$ and $\mathrm{K} 5_{\mathrm{cp}}$, in order (See Table 5). 
Table 3 Relationship between the decrease in relative water use and decrease in relative yield and yield response factor for drip-irrigated cabbage

\begin{tabular}{l|cccccccc}
\hline \multicolumn{1}{c|}{$\mathrm{IT}$} & $\mathrm{Y}$ & $\mathrm{AW}$ & $\mathrm{ET}_{\mathrm{a}}(\mathrm{mm})$ & $\mathrm{ET}_{\mathrm{a}} / \mathrm{ET}_{\mathrm{m}}$ & $\mathrm{Y}_{\mathrm{a}} / \mathrm{Y}_{\mathrm{m}}$ & $1-\left(\mathrm{ET}_{\mathrm{a}} / \mathrm{ET}_{\mathrm{m}}\right)$ & $1-\left(\mathrm{Y}_{\mathrm{a}} / \mathrm{Y}_{\mathrm{m}}\right)$ & $\mathrm{ky}$ \\
\hline $\mathrm{K} 1_{\mathrm{cp}}$ & 72.8 & 520 & 548 & 1.000 & 1.000 & 0.000 & 0.000 & 0.000 \\
$\mathrm{~K} 2_{\mathrm{cp}}$ & 57.4 & 390 & 402 & 0.734 & 0.788 & 0.266 & 0.212 & 0.797 \\
$\mathrm{~K} 3_{\mathrm{cp}}$ & 35.6 & 260 & 295 & 0.538 & 0.558 & 0.462 & 0.511 & 1.106 \\
$\mathrm{~K} 4_{\mathrm{cp}}$ & 17.0 & 130 & 170 & 0.310 & 0.234 & 0.690 & 0.766 & 1.110 \\
$\mathrm{~K} 5_{\mathrm{cp}}$ & 4.0 & 70 & 90 & 0.164 & 0.055 & 0.836 & 0.945 & 1.130 \\
\hline
\end{tabular}

IT: Irrigation treatment; Y: Yield $\left(\mathrm{t} \mathrm{ha}^{-1}\right) ; \mathrm{AW}$ : Applied Water $(\mathrm{mm})$
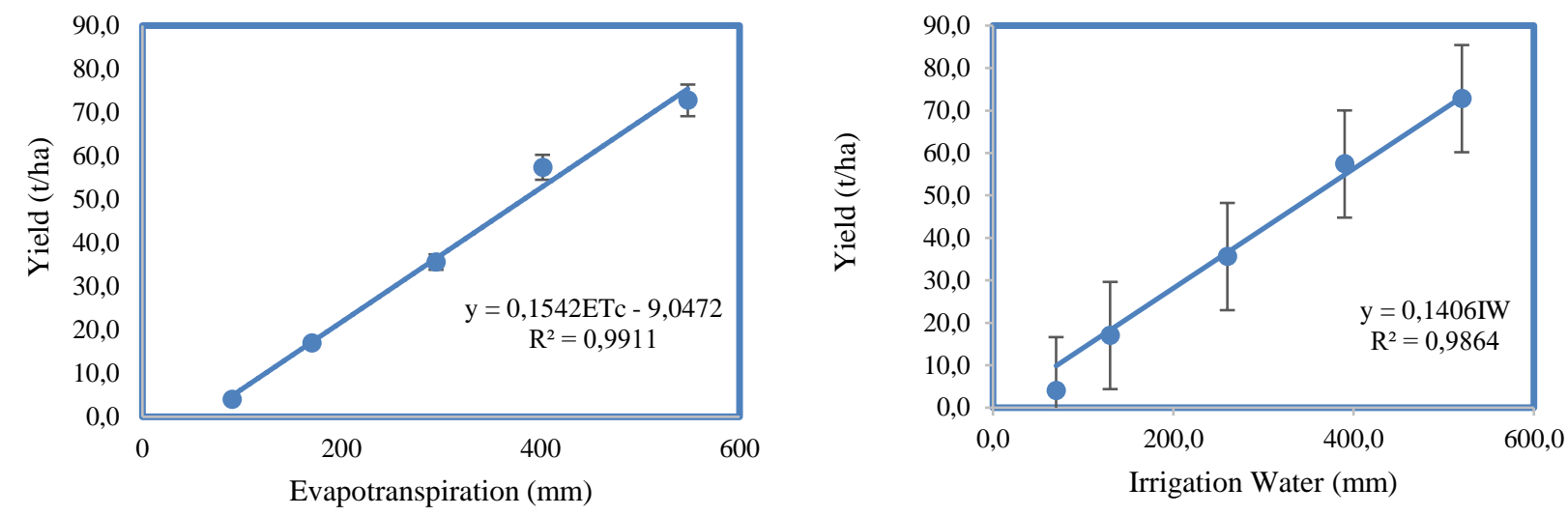

Figure 1 The relationship between crop evapotranspiration with yield and water irrigation with yield (The errors bars are SE of 14 plants)

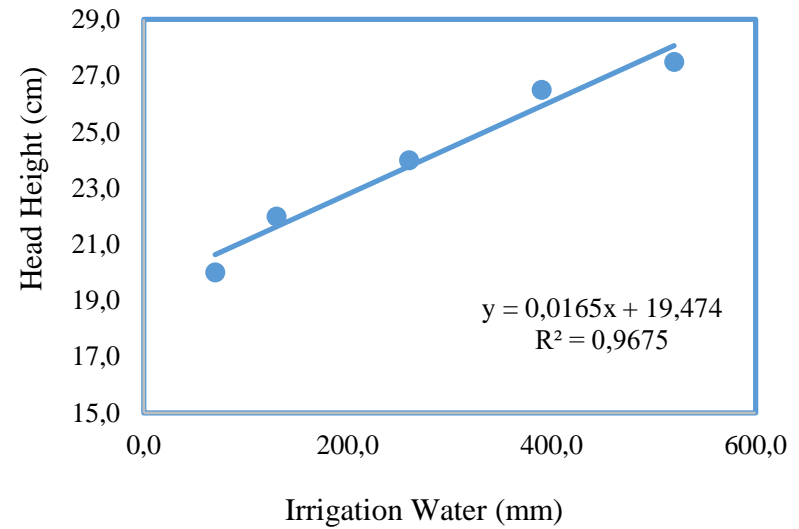

(a)

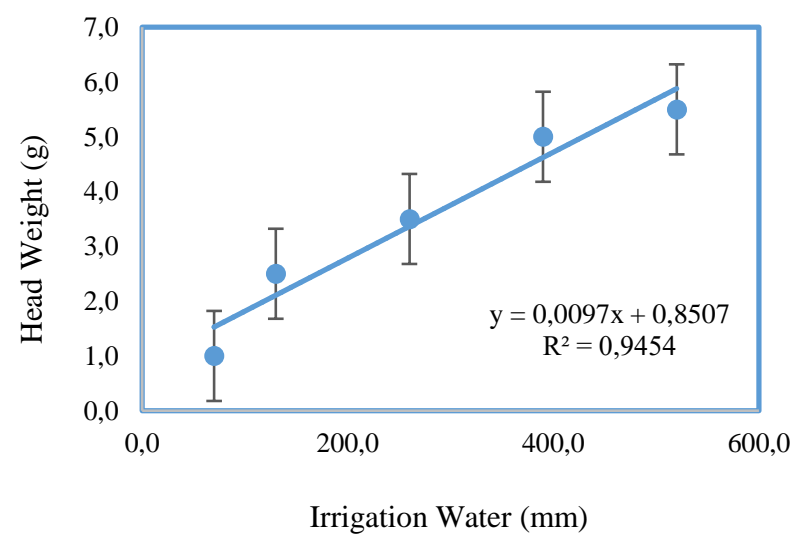

(c)

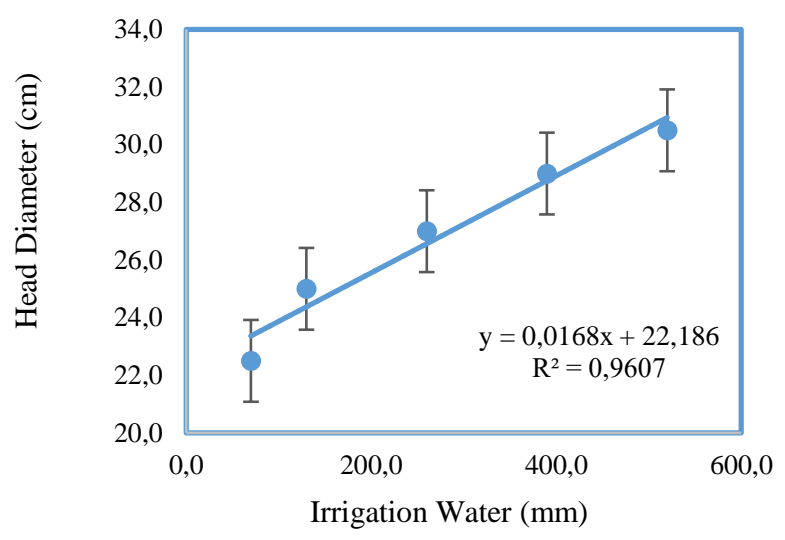

(b)

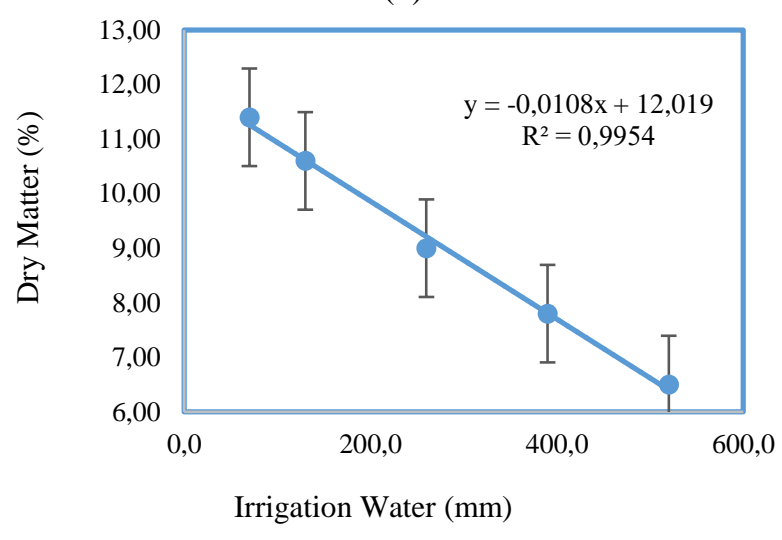

(d)

Figure 2 Relationship between applied irrigation water and head length (2a), diameter (2b), weight (2c), and dry matter (2d) (The errors bars are SE of 14 plants) 
Table 4 Effects of irrigation treatments on cabbage marketable parameters

\begin{tabular}{l|ccccc}
\hline \multicolumn{1}{c}{ IT } & Head Height $(\mathrm{cm})$ & Head Diameter $(\mathrm{cm})$ & Head Weight $(\mathrm{kg})$ & Dry Matter $(\%)$ & Yield (t/ha) \\
\hline $\mathrm{K} 1_{\mathrm{cp}}$ & $27.5^{\mathrm{a}}$ & $30.5^{\mathrm{a}}$ & $5.5^{\mathrm{a}}$ & $6.5^{\mathrm{e}}$ & $72.8^{\mathrm{a}}$ \\
$\mathrm{K} 2_{\mathrm{cp}}$ & $26.5^{\mathrm{a}}$ & $29.0^{\mathrm{ab}}$ & $5.0^{\mathrm{a}}$ & $7.8^{\mathrm{d}}$ & $57.4^{\mathrm{b}}$ \\
$\mathrm{K} 3_{\mathrm{cp}}$ & $24.0^{\mathrm{b}}$ & $27.0^{\mathrm{bc}}$ & $3.5^{\mathrm{b}}$ & $9.0^{\mathrm{c}}$ & $35.6^{\mathrm{c}}$ \\
$\mathrm{K} 4_{\mathrm{cp}}$ & $22.0^{\mathrm{bc}}$ & $25.0^{\mathrm{c}}$ & $2.5^{\mathrm{c}}$ & $10.6^{\mathrm{b}}$ & $17.0^{\mathrm{d}}$ \\
$\mathrm{K} 5_{\mathrm{cp}}$ & $20.0^{\mathrm{c}}$ & $22.5^{\mathrm{d}}$ & $1.0^{\mathrm{d}}$ & $11.4^{\mathrm{a}}$ & $4.0^{\mathrm{e}}$ \\
Treatments & $*$ & $*$ & $*$ & $*$ & $*$ \\
Blocks & $\mathrm{ns}$ & $\mathrm{ns}$ & $\mathrm{ns}$ & $\mathrm{ns}$ & $\mathrm{ns}$ \\
\hline
\end{tabular}

IT: Irrigation treatment; ** Correlation is significant at the 0.01 level, * Correlation is significant at the 0.05 level, ns non-significant

Table 5 Total water use efficiency (WUE) and irrigation water use efficiency (IWUE) values for drip irrigated cabbage at different irrigation treatments

\begin{tabular}{l|ccc}
\hline \multicolumn{1}{c|}{ IT } & Yield $\left(\mathrm{t} \mathrm{ha}^{-1}\right)$ & WUE kg mm & IWUE kg mm $^{-1}$ \\
\hline $\mathrm{K} 1_{\mathrm{cp}}$ & 72.8 & 0.133 & 0.132 \\
$\mathrm{~K} 2_{\mathrm{cp}}$ & 57.4 & 0.143 & 0.137 \\
$\mathrm{~K} 3_{\mathrm{cp}}$ & 35.6 & 0.121 & 0.122 \\
$\mathrm{~K} 4_{\mathrm{cp}}$ & 17.0 & 0.100 & 0.100 \\
$\mathrm{~K} 5_{\mathrm{cp}}$ & 4.0 & 0.000 & 0.000 \\
\hline
\end{tabular}

IT: Irrigation treatment

\section{Discussion}

In this study, irrigation treatments significantly affected yield, head height, head diameter, head weight and dry matter. Water requirements of cabbage vary from 380 to $500 \mathrm{~mm}$ depending on climate and length of growing season (Doorenbos and Kassam, 1979). Kumar and Sahu (2013) reported that the total depth of water for cabbage applied were 107 and $268 \mathrm{~mm}$, respectively. Agrawal et al. (2018) determined that water used for cabbage varied from 189 to $710 \mathrm{~mm}$. Kiziloglu et al. (2007) specified that an amount of $449.4 \mathrm{~mm}$ irrigation water and amount of $932 \mathrm{~mm}$ evaporation were applied to the plots in whole irrigation period. Wahome et al. (2009) stated that water applied for cabbage varied from 420 to $491 \mathrm{~mm}$ in different treatments and two mulch materials. Sammis and $\mathrm{Wu}$ (1989) found that treatments were arranged in a gradient irrigation design replicated three times, and were irrigated daily with amounts ranging from 0.42 to $1.94 \mathrm{~mm}$. Abdel Rahman et al. (1994) reported that the effects of two irrigation intervals (( 1 and 3 days) and three application rates $\left(3,6\right.$ and $\left.9 \mathrm{~mm} \mathrm{day}^{-1}\right)$ on growth and yield of cabbage (Brassica oleracea var. capitata L.) were studied under the relatively warm $\left(23^{\circ} \mathrm{C}\right)$ and humid (63 percent R.H.) winter conditions of Oman in the Gulf region. Smittle et al. (1994) reported that the water applied for cabbage varied from 71 to 182 mm. In the same study, pan evaporation values varied from 131 to $270 \mathrm{~mm}$. Bucks et al. (1973) indicated that the consumptive use requirement (380 $\mathrm{mm}$ of water) for high production of cabbage was about the same for all irrigation methods. Sammis et al. (1988) reported that the seasonal evapotranspiration of 205 and $209 \mathrm{~mm}$ for lettuce and Chinese cabbage, respectively. Kiziloglu et al. (2008) specified that the total class A pan evapotranspiration for red cabbage in Turkey conditions was $937 \mathrm{~mm}$. These results are notably in accordance with the irrigation water amounts and crop water consumption values obtained from previous studies (Bucks et al., 1973; Doorenbos and Kassam, 1979; Sammis et al. 1988; Sammis and Wu, 1989; Smittle et al., 1994; Abdel Rahman et al., 1994; Kiziloglu et al., 2007; Kiziloglu et al., 2008; Wahome et al., 2009; Kumar and Sahu, 2013; Agrawal et al., 2018).

The cabbage yield for 2008 year ranged between 72.8 $4.0 \mathrm{t} \mathrm{ha}^{-1}$. Based on to the results of this study, a significant effect of deficit irrigation was observed on total yield. This result is in agreement with those of (Doorenbos and Kassam, 1979; Nortje and Henrico, 1988; Sammis et al. 1988; Jangandi et al., 2000; Beltrao et al., 2000; Bogoescu, 2000; Imtiyaz et al. 2000; Salo et al., 2002; Tiwari et al., 2003; Wahome et al., 2009; Sturm et al., 2010; Himanshu et al., 2012; Kumar and Sahu, 2013; $\mathrm{Xu}$ and Leskovar, 2014; Seciu et al., 2016; Agrawal et al., 2018 ).

Yield was considerably lowered as the amount of irrigation water reduced. Quality parameters such as head height, diameter, weight and dry matter have produced a similar response to deficit irrigation as observed at yield. As expected, all irrigation treatments had higher values than the non-watered $\left(\mathrm{K} 5_{\mathrm{cp}}\right)$ treatment. These values are similar to those of previous studies (Janes, 1950; Wahome et al., 2009; Himanshu et al., 2012; Kushwah and Dwivedi, 2013; Kumar and Sahu, 2013; Xu and Leskovar, 2014; Agrawal et al., 2018). Since $K 1_{\text {cp }}$ treatments have higher head weight than the other treatments, the lowest dry matters were found at $\mathrm{K} 1_{\mathrm{cp}}$ treatments when the highest values were observed at $\mathrm{K} 5_{\mathrm{cp}}$ treatments in the study. We may conclude that significant increases in dry matter may be experienced by the increasing level of irrigation water deficit. These results are in agreement with those of (Janes, 1950; Abdel et al., 1994; Bogoescu, 2000; Wahome et al., 2009).

The maximum WUE and IWUE values were found as 0.143 and 0.137 , respectively. $\mathrm{K} 22_{\mathrm{cp}}$ treatment has had the highest as WUE and IWUE values. When the results regarding water use efficiency are compared with the findings of different researchers, they were found to be similar (Sammis et al. 1988; Himanshu et al., 2012; Kushwah and Dwivedi, 2013; Agrawal et al., 2018). Cabbage variety choice, climate, soil structure and effective use of water also affect these values. As 
explained by Davis et al., (2008), it may be attributed to the variety and applied cultural practices handling under different climate and geographical conditions. Crop yield response factor $\left(\mathrm{k}_{\mathrm{y}}\right)$ was calculated as 1.036 for cabbage. The specified value of $\mathrm{k}_{\mathrm{y}}$ (1.036) which is bigger than 1.00 shows that cabbage is susceptible to the water. Crop yield response factor $\left(\mathrm{k}_{\mathrm{y}}\right)$ also coincides with the values found by researchers who studied on similar issues (Doorenbos and Kassam, 1979; Sammis et al. 1988; Himanshu et al., 2012; Himanshu et al., 2012; Kushwah and Dwivedi, 2013; Agrawal et al., 2018).

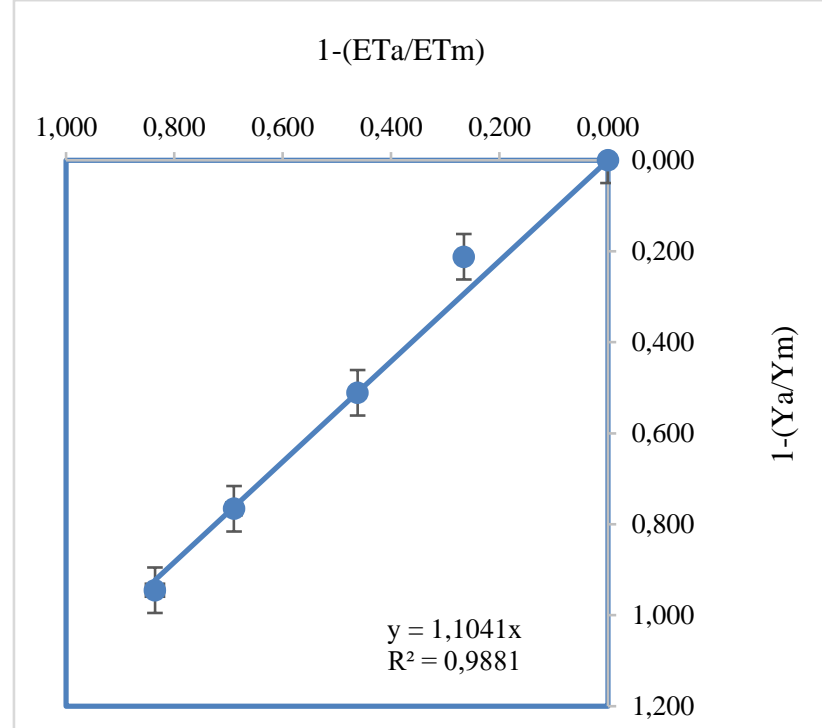

Figure 3 Relationship between relative yield decrease and relative crop evapotranspiration for cabbage throughout the total growing season

\section{Conclusions}

The ultimate goals of optimum irrigation management strategies in deficit areas are to enhance yield and quality as much as possible, increase WUE and reduce water consumption. $\mathrm{K} 2_{\mathrm{cp}}$ treatment allowed high yield and quality (in terms of head height, diameter and weight), increased WUE and reduced water use. The variety choice of cabbage, climate and soil structure also influenced to change WUE and IWUE values. Crop yield response factor of cabbages was found as 1.036 which is bigger than 1.00 shows that cabbage is susceptible to the water. $\mathrm{K} 2$ cp application $(75 \%)$ can be recommended as the most effective irrigation level for the cabbages to which drip irrigation is applied under scarce water resource and unheated greenhouse conditions.

\section{References}

Abdel Rahman HA, Ibrahim AA, Elias SA. 1994. Effect of frequency and quantity of irrigation on growth and yield of cabbage (Brassica oleracea L.). European Journal of Agronomy 3(3): 249-252.

Agrawal N, Tamrakar SK, Tripathi MP, Tiwari RB. 2018. Response of cabbage under different levels of irrigation and fertigation through drip. Int.J.Curr.Microbial.App.Sci. Special Issue (6): 750-759
Aldrich RA, Barto JW. 1989. Greenhouse Engineering. NRAES-33, 203 pp.

Anonymous. 2010. Meteorology Bulletin. Department of D.M.I, Published by Prime Minister's Office, Ankara, Turkey. pp. 111-112.

AOAC (Association of Official Analytical Chemistry). 2000. Official Methods of Analysis, 17th ed. AOAC, Washington, DC, USA.

Ayas S, Demirtas C. 2009. Deficit irrigation effects on cucumber (Cucumis sativus L. Maraton) yield in unheated greenhouse condition. Journal of Food, Agriculture \& Environment Vol. 7 (3\&4): 645-649.

Ayas S, Korukcu A. 2010. Water-yield relationships in deficit irrigated potato. Journal of Agricultural Faculty of Uludag University, Cilt 24, Say1 2, 23-36.

Ayas S, Orta H, Yazgan S. 2011. Deficit irrigation effects on broccoli (Brassica oleracea L. var. Monet) yield in unheated greenhouse condition. Bulgarian Journal of Agricultural Science. 17(4): 551- 559.

Ayas S. 2013. The Effects of different regimes on potato (Solanum Tuberosum L. Hermes) yield and quality characteristics under unheated greenhouse conditions. Bulgarian Journal of Agricultural Science, 19 (No1) 2013, 87-95.

Ayas S. 2015. The Effects of different regimes on tomato (Lycopersicon lycopersicum L. var. Hazal) yield and quality characteristics under unheated greenhouse conditions. Bulgarian Journal of Agricultural Science, 21 (No 6) 12351241.

Bar-Yosef B, Sagiv B. 1982. Response of tomatoes to N and water applied via a trickle irrigation system. II Water. Argon. J., 74: 637-639.

Beltrao J, Faria J, Miguel G, Chaves P, Trindade D. 2000. Cabbage yield response to salinity of trickle irrigation water. $\begin{array}{lll}\text { Acta Hort. 537:641-645. } & \end{array}$ 10.17660/ActaHortic.2000.537.75.

Bogle CR, Hartz TK, Nuntoez C. 1989. Comparison of subsurface trickle and furrow irrigation on plastic mulched and bare soil for tomato production. J. Am. Soc. Hortic. Sci., 114: 40-43.

Bogoescu M. 2000. The water quality and irrigation method influence about the autumn white cabbage yield. Acta Hort. 533: 447-450. DOI: 10.17660/ActaHortic.2000.533.55.

Bucks DA. 1973. Quantity and frequency of trickle and furrow irrigation for efficient cabbage production. Agronomy Journal, Vol.66, No (1): 53-57.

Büyükcangaz H, Yazgan S, Ayas S, Candogan BN, Ayas F. 2008. Effects of deficit irrigation on yield and quality of unheated greenhouse grown green bean. Journal of Food, Agriculture \& Environment 6(2): 168-172.

Clough GH, Locasio SJ, Olsen SM. 1990. The yield of successively cropped polyethylenemulched vegetables as affected by irrigation method and fertilization management. J. Am. Soc. Hortic. Sci. 115: 884-887.

Davis AR, Webber CL, Perkins-Veazie P, Ruso V, Lopez Galarza S, Sakata Y. 2008. A Review of production systems on watermelon quality. Roceedings of the IXth EUCARPIA Meeting on 98 Genetics and Breeding of Cucurbitaceae (M. PITRAT, editor), INRA, Avignon, France, 515-520.

Demirtas C, Ayas S. 2009. Deficit irrigation effects on pepper (Capsicum annuum L. Demre) yield in unheated greenhouse condition. Journal of Food, Agriculture \& Environment 7 (3\&4): $989-993$.

Doorenbos J, Pruitt WO. 1977. Guidelines for predicting crop water requirements. FAO Irrigation and Drainage Paper No. 24, Food and Agricultural Organization of the United Nations, Rome.

Doorenbos J, Kassam AH. 1979. Yield response to water. FAO Irrigation and Drainage Paper No. 33, Rome. 
Enoch HZ, Enoch Y. 1999. The history and geography of greenhouse. In Stanhil, G. and Enoch, H.Z. (eds). Greenhouse Ecosystems. Ecosystems of the World 20. Elsevier, Amsterdam, pp.1-15.

FAOSTAT. 2014. Food and Agriculture Organization Corporate Statistical Database. http://www.fao.org/faostat/en/\#data/QC

FAOSTAT. 2016. Food and Agriculture Organization Corporate Statistical Database. http://www.fao.org/faostat/en/\#data/QC

Hartz TK. 1993. Drip irrigation scheduling for fresh market tomato production. Hort. Science, 28: 35-37.

Himanshu SK, Kumar S, Kumar D, Mokhtar A. 2012. Effects of lateral spacing and irrigation scheduling on drip irrigated cabbage (Brassica oleracea) in a semiarid region of India. Research Journal of Engineering Sciences 1(5): 1-6.

Howell TA, Cuenca RH, Solomon KH. 1990. Crop yield response. Chapter 5 in management of farm Irrigation Systems, pp. 93-122. Edited by G. J. Hoffman, T. A. Howell, and K. H. Solomon. ASAE Monograph, ASAE, St. Joseph, Michigan. 1040 pp.

Imtiyaz M, Mgadla NP, Manase SK, Chendo K, Mothobi EO. 2000. Yield and economic return of vegetable crops under variable irrigation. Irrigation Science 19(2): 87-93.

Janes BE. 1950. The effect of irrigation, nitrogen level and season on the composition of cabbage. Plant Physiology 25 (3): 441-452.

Jangandi S, Shekar BG, Sridhara S. 2000. Water use efficiency and yield of cabbage as influenced by drip and furrow methods of irrigation. Indian Agriculturist 44(3/4):153-155.

Kanber R. 1984. Çukurova koşullarında açık su yüzeyi buharlaşmasından yararlanarak birinci ve ikinci ürün yerfistığının sulanması. Bölge Topraksu Araştırma Enstitüsü. Yay. 114 (64), 93, Tarsus.

Kiziloglu FM, Turan M, Sahin U, Angin I, Anapali O, Okuroglu M. 2007. Effects of wastewater irrigation on soil and cabbage plant chemical properties. J. Plant Nutr. Soil Sci. 170: 166-172. DOI: 10.1002/jpln.200621971

Kiziloglu FM, Turan M, Sahin U, Kuslu Y, Dursun A. 2008. Effects of untreated and treated wastewater irrigation on some chemical properties of cauliflower and red cabbage grown on calcareous in Turkey. Agricultural Water Management 95: 716-724. doi:10.1016/j.agwat.2008.01.008.

Kruger E, Schmidt G, Brucker U. 1999. Scheduling strawberry irrigation based upon tensiometer measurement and a climatic water balance model. Scienta Horticulturae 81: 409-424. doi:10.1016/S0304-4238(99)00030-8.

Kumar P, Sahu RL. 2013. Effects of irrigation and fertigation levels on cabbage. An Asian Journal of Soil Science 8(2): 270-274.

Kushwah SS, Dwivedi YC. 2013. Effect of different methods of irrigation and moisture regimes on yield and water economy in cabbage (Brassica oleracea L. var. capitata). Asian J. Hort 8(1): 43-45.

Lorenz OA, Maynard DN. 1980. Knott's hand book for vegetable growers. 2nd edt. John Wiley Sons, New York.

McNeish CM, Welch NC, Nelson RD. 1985. Trickle irrigation requirements for stawberries in coastal California. J. Am. Soc. Hortic. Sci. 110: 714-718.

Nortje, PF, Henrico PJ. 1988. The effects of suboptimal irrigation and intra-row spacing on the yield and quality of cabbages. Acta Hort. 228(2):163-170.
Ritchie JT, Johnson BS. 1990. Irrigation of agricultural crops. Agronomy Monograph, No 30: 363-390.

Salo T, Suojala T, Kallela M. 2002. The effect of fertigation on yield and nutrient uptake of cabbage, carrot and onion. Acta Hort. 571:235-241. DOI: 10.17660/ActaHortic.2002.571.28.

Sammis TW, Kratky BA, Wu IP. 1988. Effects of limited irrigation on lettuce and Chinese cabbage yields. Irrig. Sci. (9): 187-198. https://doi.org/10.1007/BF00275431.

Sammis T, Wu IP. 1989. Deficit irrigation effects on head cabbage production. Agricultural Water Management, Vol.16, Issue (3): 229-239. https://doi.org/10.1016/03783774(89)90005-X.

Seciu AM, Oancea A, Gaspar A, Moldovan L, Craciunescu O, Stefan L, Petrus V, Georgescu F. 2016. Water use efficiency on cabbage and cauliflower treated with a new biostimulant composition. Agriculture and Agricultural Science Procedia 10: 475-484. https://doi.org/10.1016/j.aaspro.2016.09.019.

Smittle DA, Dickens WL, Stansell JR. 1994. Irrigation regimes affect cabbage water use and yield. J. Amer. Soc. Hort. Sci. 119(1): 20-23.

Steel RGD, Torrie JH. 1980. Principles and procedures of statistics. A biometrical approach. McGraw-Hill, NewYork, pp.186-187.

Stewart JI, Misra RD, Pruitt WO, Hagan RM. 1975. Irrigating corn and sorghum with a deficient water supply. Trans. ASAE, 18: 270-280.

Sturm M, Marsic NK, Zupanc V, Zeleznik BB, Lojen S, Pintar M. 2010. Effect of different fertilization and irrigation practices on yield, nitrogen uptake and fertilizer use efficiency of white cabbage (Brassica oleracea var. capitata L.). Scientia Horticulturae 125(2):103-109. DOI: 10.1016/j.scienta.2010.03.017.

Tiwari KN, Singh A, Mal PK. 2003. Effect of drip irrigation on yield of cabbage (Braccica oleracea L. var. capitata) under mulch and non-mulch conditions. Agricultural Water Management (58): 19-28. https://doi.org/10.1016/S03783774(02)00084-7.

Xu C, Leskovar D.I. 2014. Growth, physiology and yield responses of cabbage to deficit irrigation. Hort. Sci., 41(3):138-146.

Von Elsner B., Briassoulis D, Waaijenberg D, Mistriotis A, Von Zabeltizt C. H. R, and Gratraud J. 2000. Mechanical properties of covering materials for greenhouses. Part I. General overview. J. Agric. Eng. Res., 67: 81- 96.

Vural H, Eşiyok D, Duman İ. 2000. Cultivated vegetables (Kültür sebzeleri), Ege University press, 440 p. (In Turkish)

Wahome PK, Shongwe V, Mbewe DN. 2009. Response of cabbage (Brassica oleraceae var. capitata) to mulching and different irrigation regimes. Am-Euras. J. Agric \&. Environ. Sci. 6(6): 662-669.

Yazgan S, Ayas S, Demirtas C, Buyukcangaz H, Candogan B.N. 2008. Deficit irrigation effects on lettuce (Lactuca sativa var. Olenka) yield in unheated greenhouse condition. Journal of Food, Agriculture \& Environment 6(2):168-172.

Yuan BZ, Sun J, Nishiyama S. 2003. Effect of drip irrigation on strawberry growth inside a plastic greenhouse. Biosystems Engineering, 87 (2): 237- 245. 